\title{
Analysis of shape and size variation of the first lower molar in Far-Eastern grey voles of genus Alexandromys (Rodentia: Cricetidae) from Russian fauna using geometric morphometrics
}

\author{
Leonid L. Voyta*, Fedor N. Golenishchev \& Mikhail P. Tiunov
}

ABSTRACT. The variation of quantitative characters of the first lower molar was analysed in nine species of Far-Eastern voles Alexandromys from Russian fauna. Canonical variation analysis revealed that main differences were associated with "oeconomus-like" fusion, and clearly differentiates $A$. oeconomus, $A$. mongolicus and $A$. gromovi from other species. The results of UPGMA cluster analysis based on the average Procrustes distances did not agree with recent molecular studies. Discriminant analysis of Procrustes coordinates of 19 landmarks showed that the percentage of correct species classifications of samples vary from $50 \%$ to $100 \%$. Linear measurements together with shape features can be used for identification of the following species: A. oeconomus, A. mongolicus, and A.sachalinensis. Shape of enamel loops of the first lower molar of Far-Eastern grey voles can be used for species identification, but not for phylogenetic analysis.

KEY WORDS: Alexandromys, Far-Eastern grey voles, Rodentia, Russian fauna, relationships, species identification, first lower molar, geometric morphometrics.

Leonid L.Voyta [desmana.zin@gmail.com], Zoological Institute of the Russian Academy of Sciences. Universitetskaya emb., 1, St.-Petersburg, 199034, Russia; Institute of Natural Resources, Ecology and Cryology of the Siberian Division of the Russian Academy of Sciences. Butina st., 26, Chita, 672090, Russia; Fedor N. Golenishchev [f_gol@mail.ru], Zoological Institute of the Russian Academy of Sciences. Universitetskaya emb., 1, St.-Petersburg, 199034, Russia; \& Mikhail P. Tiunov [tiunov@ibss.dvo.ru], Institute of Biology and Soil Science, Far East Division, Russian Academy of Sciences, Vladivostok 690022, Russia.

\section{Анализ изменчивости формы и размеров первого нижнего коренного зуба дальневосточных серых полевок рода Alexandromys (Rodentia: Cricetidae) фоауны России c использованием геометрической морфометрии}

\author{
Л.Л. Войта*, Ф.Н. Голенищев, М.П. Тиунов
}

РЕЗЮМЕ. В работе проанализирована изменчивость количественных признаков первого нижнего коренного зуба девяти видов дальневосточных полевок рода Alexandromys (Rodentia: Cricetidae) фауны России. Канонический вариационный анализ выявил, что основные различия связаны с «экономусным» слиянием, которое хорошо дифференцирует A. oeconomus, A. mongolicus и $A$. gromovi от других видов. Результат кластерного анализа (метод UPGMA) основанного на средних значениях прокрустовых дистанций не согласуется с результатами современных молекулярных исследований. Дискриминантный анализ по прокрустовым координатам 19 меток показал точность корректной классификации для всех пар видов от 50\% до 100\%. Линейные промеры в совокупности с параметрами формы могут быть использованы для определения следующих видов: A. oeconomus, A. mongolicus, A. sachalinensis. Форма эмалевых петель первого нижнего коренного зуба дальневосточных серых полевок может быть использована для определений вида, но не для выяснения родственных взаимоотношений в группе.

КЛЮЧЕВЫЕ СЛОВА: Alexandromys, дальневосточные серые полевки, Rodentia, фауна России, филогенетические отношения, определение видов, первый нижний коренной зуб, геометрическая морфометрия.

* Corresponding author 


\section{Introduction}

Investigations of taxonomic status and relationships of the Far-Eastern grey voles from East Siberia and Russian Far East have a long history. This issue was reviewed several times (Poljakov, 1881; Vinogradov, 1933; Ognev, 1950; Vinogradov \& Gromov, 1952; Gromov et al., 1963; Kuziakin, 1963; Gromov \& Polyakov, 1977; Zagorodnyuk, 1990; Pozdniakov, 1993; Meyer et al., 1996; Litvinov, 2001; Kartavtseva et al., 2008; Frisman et al., 2009; Sheremetyeva et al., 2009; Bannikova et al., 2010; Lissovsky et al., 2010; Lissovsky \& Obolenskaya, 2010, 2011; Haring et al., 2011; Abramson \& Lissovsky, 2012).

At present the Far-Eastern voles are assigned to the genus Alexandromys Ognev, 1914 (Abramson \& Lissovsky, 2012). We accept this opinion and will use "Alexandromys" instead "Microtus" below.

During the last three-four decades the discussion on taxonomy of Far-Eastern voles was focused on two main questions: (a) taxonomic relationships between species, and (b) species identification.

Karyological studies of the second half of the 20th century revealed high chromosomal variation in $A$. maximowiczii Schrenk, 1858 (Kovalskaja et al., 1980; Kartavtseva et al., 2008), and three new cryptic taxa were described: A. mujanensis Orlov et Kovalskaja, 1975, $A$. evoronensis Kovalskaja et Sokolov, 1980, A. maximowiczii gromovi Vorontsov et al., 1988. Re-examination of Alexandromys species using karyological techniques (including hybridological studies) supported the validity of five species in the subgenus, which were included previously in different species groups (Meyer et al., 1996) or even subgenera (Gromov \& Erbaeva, 1995). These species were: A. fortis Büchner, 1889, A. maximowiczii, A. sachalinensis Vasin, 1955, A. mujanensis and $A$. evoronensis. In spite of the published identification keys and detailed morphological description (Gromov \& Polyakov, 1977; Golenishchev, 1982) these five species were difficult to identify morphologically (Pozdniakov, 1993; Voyta \& Golenishchev, 2007, 2008; Voyta et al., 2011). The similarity in the shape of enamel loops of molars between different species (Rörig \& Börner, 1905; Hinton, 1929; Zimmermann, 1952, 1959; Angermann, 1973; Gromov \& Polyakov, 1977; Koenigswald, 1980; Butler, 1985) causes a considerable problem for diagnostics, particularly dealing with fossil remains (Rabeder, 1981; Kotlia \& Mathur, 1992). In this case, the geographical distribution becomes an important criterion for species identification (Shenbrot \& Krasnov, 2005), since three species (A. sachalinensis, $A$. mujanensis and $A$. evoronensis) have a restricted distribution, while two others were found to have overlapping ranges but differ in ecological preferences (Gromov \& Erbaeva, 1995; Meyer et al., 1996). Some studies discussed including of Microtus mongolicus Radde, 1861 (Meyer et al., 1996) and M. middendorffii Poljakov, 1881 (Zagorodnyuk, 1990) into the subgenus Alexandromys also.
During the last decade the species number and taxonomic relationships of the Far-Eastern voles were defined more exactly (Frisman et al., 2009; Sheremetyeva et al., 2009, Bannikova et al., 2010; Lissovsky et al., 2010; Haring et al., 2011; Lissovsky \& Obolenskaya, 2011; Abramson \& Lissovsky, 2012). The inclusion of A. mongolicus and A. middendorffii into Alexandromys subgenus was supported with mitochondrial and morphological data (Bannikova et al., 2010; Lissovsky et al., 2010; Haring et al., 2011; Lissovsky \& Obolenskaya, 2011). One taxon of subspecific rank $A . m$. gromovi was elevated to the species status - A. gromovi (Sheremetyeva et al., 2009), which is closely phylogenetically related to $A$. middendorffii and $A$. mongolicus (Bannikova et al., 2010; Lissovsky et al., 2010). According to this information, nine species inhabit Russian part of Alexandromys distribution: A. fortis, $A$. maximowiczii, A. sachalinensis, A. mujanensis, $A$. evoronensis, $A$. middendorffii, $A$. mongolicus, $A$. gromovi and A. oeconomus Pallas, 1776 (Abramson \& Lissovsky, 2012).

Despite of some progress in the phylogeny and taxonomic composition of the genus, the problem of species identification is still pressing. It is especially true for fossil remains which are commonly identifiable on the basis of occlusal molar pattern only (Rabeder, 1981; Agadzhanian \& Yatsenko, 1984; Kazantseva \& Tesakov, 1998; Martin, 1998; Tesakov, 2005). The identifying of fossil material demands special care in using modern morphometric techniques applied to the grey voles' dentition. Thereby, the main tasks of the present study is to analyse an interspecific variation of the first lower molar (m1) of Far-Eastern grey voles from Russian fauna and to evaluate the identification power of the dental quantitative features in this group of voles.

\section{Material and methods}

We studied collections of Zoological Institute of the Russian Academy of Sciences (ZIN; St.-Petersburg, Russia), Zoological Museum of Moscow State University (ZMMU; Moscow, Russia), Institute of Plant and Animal Ecology of the Russian Academy of Sciences (IPAE; Yekaterinburg, Russia), Institute of Biology and Soil Science of the Far East division of the Russian Academy of Sciences (IBSS; Vladivostok, Russia), as well as two private collections: Marina N. Meyer's Private Collection (MM), stored in Zoological Institute and field collection (FN IBSS), stored in Institute of Biology and Soil Science (Appendix 1). The museum specimens, mentioned in the text, were labelled with museum abbreviation followed with collection ID, for example: IBSS-10944.

In total, 433 left $\mathrm{ml}$ of nine species mentioned above were analysed. This sample includes animals from captivity as well as wild animals.

Taking into account problems with species identification (Voyta \& Golenishchev, 2008; Voyta et al., 

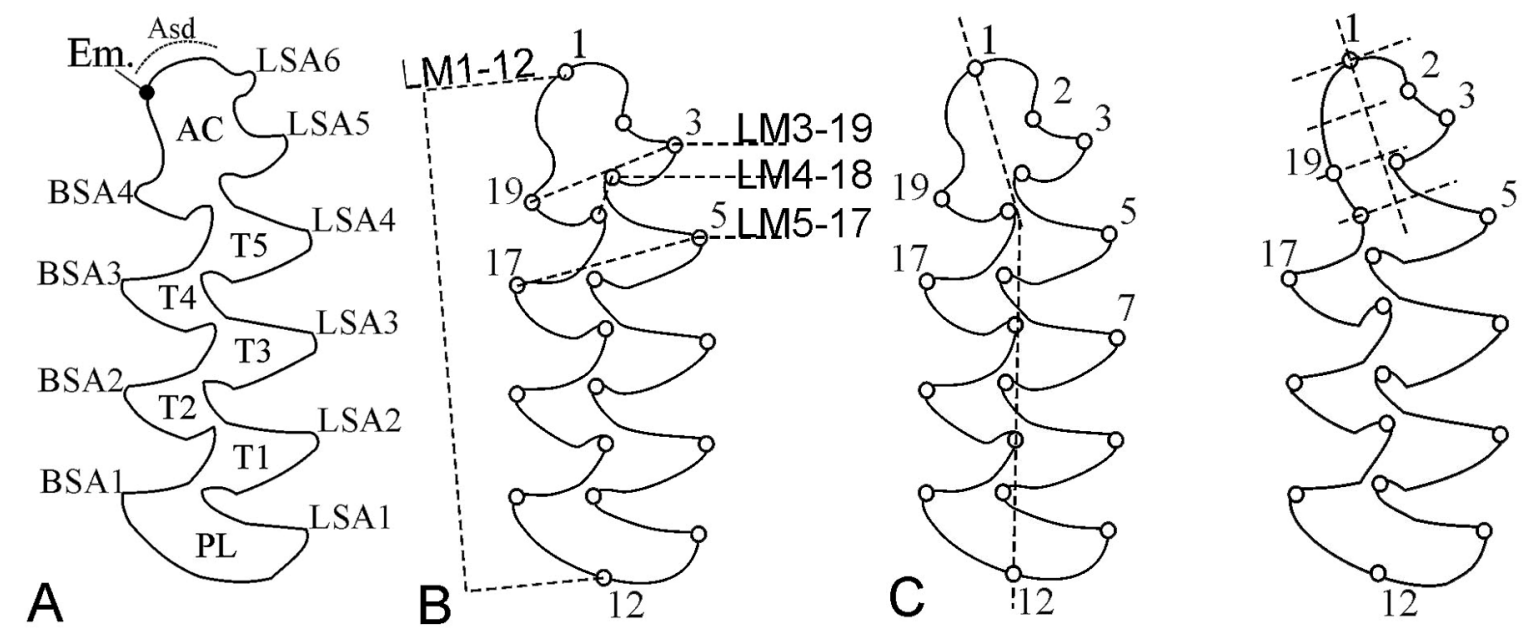

Figure 1. Scheme of morphological terms, measurements and landmarks position. A - the elements of the $\mathrm{m} 1$ occlusal pattern of grey voles: "Asd" — the position of anterior dentine tract or "anterosinuid" (terminology of the tracts following G. Rabeder (1981)); "Em." — the osslusal view of the enamel-dentine boundary ("Linea sinuosa" of G. Rabeder) of the anterior dentine tract; "T $n$ " - the triangles of the occlusal surface; "AC" — anterior cap; "PL" — posterior lobe; "BSA $n$ " — buccal salient angles; "LSA $n$ " - lingual salient angles (terminology of the occlusal surface following Van der Meulen (1973)); B measurements of $\mathrm{m} 1 ; \mathbf{C}$ - examples of landmark position on the $\mathrm{m} 1$ (A. maximowiczii, and two A. oeconomus respectively).

2011), we studied samples from allopatric localities (except two samples nos. 8 and 15 from Amur Region, see Appendix 1) or specimens with karyological or mitochondrial identification (Gileva, 1972; Meyer et al., 1996; Kartavtseva et al., 2008; Sheremetyeva et al., 2010; Bannikova et al., 2010; Lissovsky et al., 2010; Haring et al., 2011).

The occlusal surface of $\mathrm{m} 1$ of each specimen was drawn using binocular microscope Zeiss Stemi SR (ocular $10 \times 25$, zoom =5). Each image was captured using the flatbed scanner Epson Perfection V300 with a resolution of $200 \mathrm{dpi}$. The shape of each occlusal surface was studied with 19 two-dimensional Cartesian landmarks. The scheme of landmarks position was taken from the articles of McGuire $(2010,2011)$ with some modifications (Fig. 1). Teeth were landmarked three times in order to minimize landmark orientation error. The analysis was performed on the average values of these three attempts.

Variables: centroid size (CS), Procrustes coordinates (PrC), relative warps (RW), were calculated using standard methods (Bookstein, 1991; Zelditch et al., 2004) using the program MorphoJ (Klingenberg, 2011). The alignment of specimens was based on the CS by General Procrustes Analysis module of MorphoJ (Rohlf \& Slice, 1990; Klingenberg, 2011). Four linear measurements between $1-12,5-17,3-19,4-18$ pairs of landmarks (Fig. 1) were obtained in the program IMP 6 (Sheets, 2001).

We analysed CS and RW variation in two species (A. evoronensis and A. maximowiczii) using One-way ANOVA and MANOVA using the program PAST (Hammer et al., 2001) for evaluation of the age effect on the shape and size of $\mathrm{m} 1$ (Appendix 2). The analysis included three age categories: "subadults" (SAD, immature animals, about 1 month old); "adults1" (AD1, mature animals, about 3 months old); "adults2" (AD2, mature animals, about 5 months old). Age stages were detected using three criterions: (a) the third upper molar talon development (for elimination of juvenile specimens); (b) the skull crests development (this feature allows to recognize all three stages) (Larina, 1974); (c) month of capture (separating winter, spring and summer voles).

Sexual dimorphism of craniometrical parameters was found in Alexandromys previously (Meyer et al., 1996; Lissovsky \& Obolenskaya, 2010, 2011). However, we did not find significant differences between males and females in tooth shape and size within this group of voles (Voyta \& Golenishchev, 2007). Thus we ignored sexual variation during calculations.

In order to avoid species mixing inside the samples, we evaluated the distribution of CS values, expecting normal distribution in mono-species samples. The distribution was initially tested using Shapiro-Wilk's test (W). If distribution within species deviated from normal, we divided this species into several samples. For this purpose, we aggregated geographical samples randomly, each time testing these aggregations for normality. The number and composition of these aggregations were chosen manually. The final samples were tested for homogeneity using Levine's test.

One-way ANOVA was used for comparison of linear measurements. MANOVA was used for shape comparison on the basis of the first $12 \mathrm{RW}$.

Ordination was carried out using two methods. The first is relative warps analysis (RWA) and the second - canonical variation analysis (CVA) using RW as 
variables. A variable, containing labels for 14 samples (see below) was used as grouping variable for CVA.

Hierarchical cluster analysis was performed on the basis of average values of Procrustes coordinates of 14 samples. Euclidean distances and UPGMA method of clustering were used. We applied a cophenetic correlation coefficient for an estimation of compliance between data matrix and dendrogram (Baryshnikov \& Puzachenko, 2009).

We used canonical discriminant analysis (DA) with permutation test (10000 permutations) to evaluate differences inside each pair of samples. Additionally, we analysed multivariate morphometric measurements (PrC) with DA in order to determine the diagnostic capabilities of 19 landmarks scheme.

Statistical analyses (ANOVA, MANOVA, CVA, UPGMA cluster analysis) were performed in PAST v. 2.04 (Hammer et al., 2001) and MorphoJ (RWA, DA).

\section{Results}

\section{Age variation}

One-way ANOVA of CS and MANOVA of RW did not find significant differences between age groups in both species: $A$. evoronensis: $\lambda$ Wilks $=0.551, \mathrm{~F}_{\mathrm{RW}}=$ $1.302, \mathrm{p}=0.307 ; \mathrm{F}_{\mathrm{CS}}=0.233, \mathrm{p}=0.637 ;$ A. maximowic$z i i: \lambda W i l k s=0.234, \mathrm{~F}_{\mathrm{RW}}=2.287, \mathrm{p}=0.142 ; \mathrm{F}_{\mathrm{CS}}=0.637$, $\mathrm{p}=0.540$. Therefore, age differences were omitted as negligible in further analysis.

\section{Distribution of CS values across the sample}

We did not find any deviations from normal distribution of CS values in the following species: A. evoronensis, A. fortis, A. maximowiczii, A. mongolicus, A. mujanensis, A. gromovi (W=0.908-0.982; $>>0.05)$. Three species: $A$. sachalinensis, $A$. oeconomus and $A$. middendorffii displayed a significant deviation from normal distribution $(\mathrm{p}<0.05)$.

The sample of Sakhalin's vole includes only animals of the same age from captivity and we couldn't separate it. We obtained normally distributed samples of $A$. oeconomus, after it's subdividing into three parts: "ecoA" - samples nos. 15-17 (see Appendix 1; W = $0.949, \mathrm{p}=0.178)$; “ecoB" — sample from Kamchatka no. $18(\mathrm{~W}=0.915, \mathrm{p}=0.214)$; "ecoC" — sample from Shumshu Island no. $19(\mathrm{~W}=0.921, \mathrm{p}=0.119)$. Four normally distributed samples were obtained for $A$. middendorffii: "mdA" — the largest voles nos. 20, 21, 27, $28(\mathrm{~W}=0.947, \mathrm{p}=0.157)$; "mdB" - smaller voles nos. 22-24 (W = 0.957, $\mathrm{p}=0.193)$; "mdC" — the smallest voles from Yamal Peninsula no. $26(\mathrm{~W}=0.915, \mathrm{p}=$ $0.188)$; "mdD" — voles of medium size nos. 25, 29, 30 $(\mathrm{W}=0.946, \mathrm{p}=0.051)$. There was not any geographic pattern in such samples subdivision.

None of 14 samples displayed deviations from homogeneity $(\mathrm{p}=0.61)$.

Thus, 14 samples were used in the following analysis: one sample for each of seven species mentioned above; three samples of root vole; four samples of Middendorff's vole.

\section{Size}

One-way ANOVA of four linear measurements showed significant differences between samples $\left(\mathrm{F}_{\mathrm{LM1-12}}=\right.$ 8.662, $\mathrm{p}<0.001 ; \mathrm{F}_{\mathrm{LM} 5-17}=8.624, \mathrm{p}<0.001 ; \mathrm{F}_{\mathrm{LM} 3-19}^{\mathrm{LM1}-12}=$ 9.270, $\left.\mathrm{p}<0.001 ; \mathrm{F}_{\mathrm{LM} 4-18}^{\mathrm{LM}-17}=6.070, \mathrm{p}<0.001\right)$.

According to published information Far-Eastern voles could be divided into three size-groups: small, medium, and large (Meyer et al., 1996). According to our results, the length of $\mathrm{m} 1$ (LM1-12) also allows to divide voles in three size classes: small (A. mongolicus, A. gromovi, A. oeconomus "ecoB", A. middendorffii "mdB" and "mdC "), middle (A. maximowiczii, $A$. oeconomus "ecoA", A. middendorffii "mdA" and "mdD"), and large (A. evoronensis, A. fortis, A. mujanensis, A. sachalinensis) (Tab. 1; Fig. 2A). Sample of $A$. oeconomus "ecoC" has a great range of variation among large and medium-size voles. The width of anteroconid (AC) base (LM5-17) (Tab. 1, Fig. 2B) also allows to divide samples into three groups. In this case, however, the narrowest AC base have $A$. mongolicus and $A$. gromovi, and after them $A$. middendorffii "mdB" and "mdC" and A. maximowiczii. The widest AC base has $A$. fortis, the rest of the samples formed middle group. The distance between angles BSA4 and LSA5 (LM319) (Tab. 2, Fig. 2C) showed the differences between $A$. mongolicus, A gromovi, all samples of $A$. oecono$m u s$, "mdC" and others samples. The width of "oeconomus-like" (LM4-18) fusion showed significant differences between $A$. oeconomus "ecoA" and "ecoC" and others samples (Tab. 2, Fig. 2D).

\section{Shape}

MANOVA of RW revealed significant differences between samples ( $\ddot{W}$ ilks $=0.008, F=15.92, p<0.001)$. Hotelling's test revealed significant differences between means of all pairs of species, except $A$. evoronensis and A. mujanensis $(\mathrm{p}=0.155)$. The Levine's test did not find deviations from homogeneity of variances for each of 14 samples $(\mathrm{p}>0.05)$.

Ordination based on RWA displayed differentiation of species with "oeconomus-like" fusion: A. oeconomus, A. mongolicus and $A$. gromovi. Other species display wide overlapping of the specimen clouds (Fig. $3 \mathrm{~A})$. The shape variation in the first two RW axes is shown on the transformation grid (Fig. 3B).

The distribution of samples in the plain of the first two axes of CVA is shown in Fig. 4. The first canonical variable (about $61 \%$ of total variance) correlated with RW 1 (22.1\%), and reflects the degree of "oeconomuslike" fusion, as well as the development of BSA4 and the configuration of the AC lingual angles (LM2, 3, 4) (Fig. 3B).

The second canonical variable (about 17\%) correlated with RW 2 (12.5\%) and RW 3 (9.3\%), thus it reflects AC proportions (length of anterior cap LM118; small displacement of lingual angle LM5 to anterior relative buccal angle LM17), and depth of lingual reentrant angle LM2.

The results of cluster analysis reflected morphological similarity between samples (Fig. 5). It is possible to 

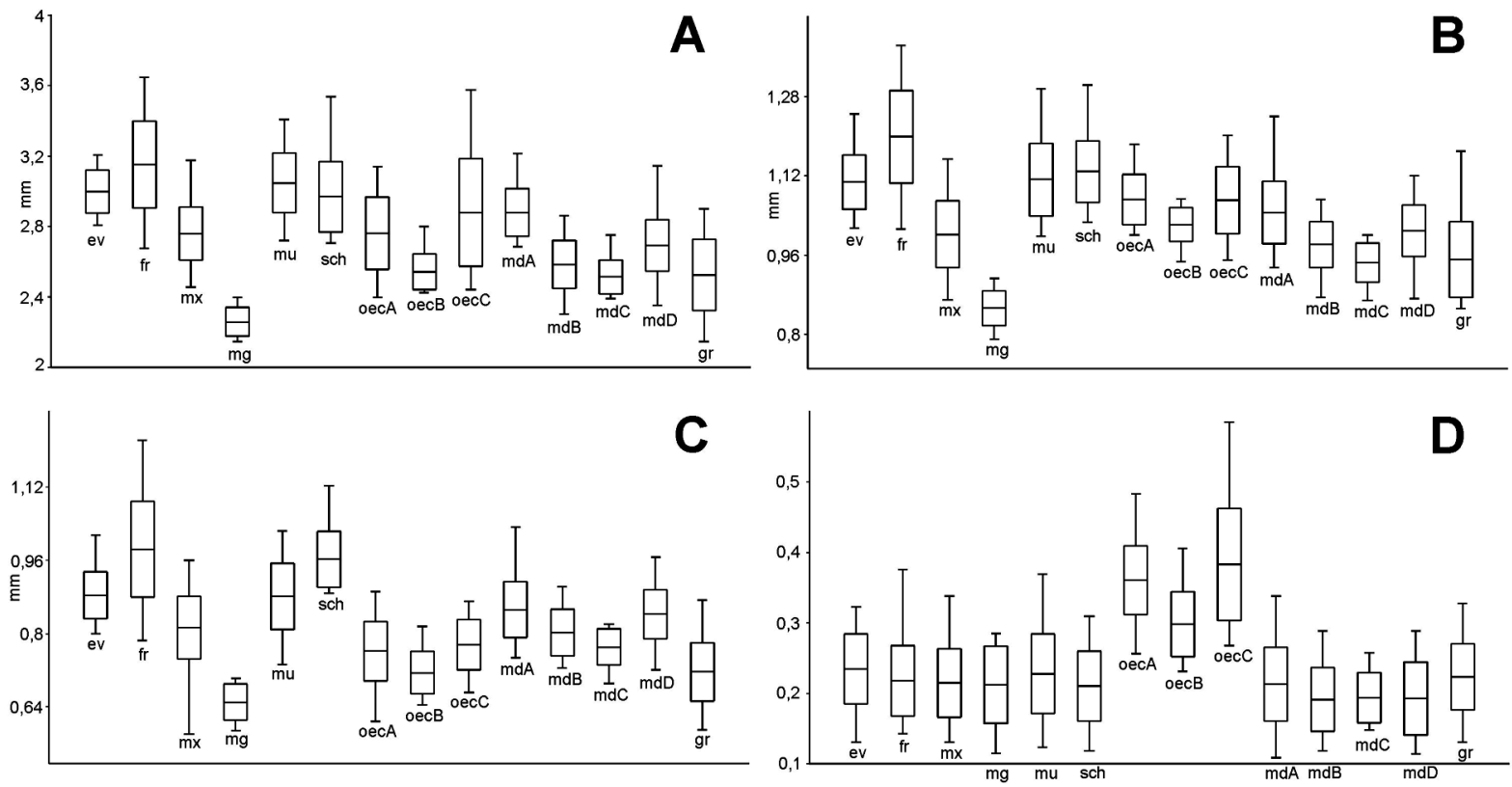

Figure 2. Box-whisker plot of m1 length (A; LM1-12), anteroconid base width (B; LM5-17), anterior cap width (C; LM319), width of "oeconomus-like" fusion (D; LM4-18) among species. ev $-A$. evoronensis; fr $-A$. fortis; $\mathrm{mx}-A$. maximowiczii; $\mathrm{mg}-A$. mongolicus; mu - A. mujanensis; sch - A. sachalinensis; oecA,B,C - samples of $A$. oeconomus (see text); mdA-D — samples of $A$. middendorffii; gr - A. gromovi; whiskers - max-min; box — standard deviation.

find features which differentiate taxa inside several clusters.

The first cluster is $A$. oeconomus + A. mongolicus . The features differentiating these two species are: (1a) anterior shifting of LM16 and LM18 in A. mongolicus; (1b) buccal shifting of LM19 in A. mongolicus; (1c) anterior-lingual shifting of LM1 and more posterior position of LSA5 (LM2, 3) in A. mongolicus. In addition, A. oeconomus is larger than $A$. mongolicus (Figs 2 and 6).

The second cluster is A. sachalinensis + "mdB-D". The differentiating features are: $(2 \mathrm{a})$ deeper reentrant angle (LM4) in A. middendorffii; (2b) buccal shifting of BSA4 relative to stable position of LM18 in A. sachalinensis. In addition, $A$. sachalinensis is larger than $A$. middendorffii (mdB-D).

The third cluster is A. maximowiczii $+\mathrm{mdA}$. The differentiating features are: (3a) wider PL in $A$. maximowiczii; (3b) anterior shifting of buccal reentrant angles $(\mathrm{LM} 14,16)$ relative to stable lingual angles (LM4, $6,9,10$ ) in $A$. maximowiczii; (3c) posterior shifting of BSA4 (LM19) relative to stable LM18 in A. maximowiczii.

The fourth cluster is $A$. mujanensis $+A$. evoronensis. The differentiating features are: (4a) posterior shifting of LM18 relative to stable LM19 in A. mujanensis; (4b) buccal shifting of LM4 in A. mujanensis.

Value of cophenetical correlation coefficient between initial and patristic distance matrices was high $(\mathrm{r}=0.909)$.

The results of cross-validation are presented in Tab. 3. Minimum percentage of correct classification was indicated for the pair $A$. mongolicus $-A$. evoronensis $(50 \%)$ and the pair $A$. evoronensis-A. mujanensis $(55.5 \%)$. The highest degree of correct classification was found for A. oeconomus and A. gromovi. However, $A$. oeconomus was classified with less accuracy in comparison with other species (e.g. A. oeconomus-A. mongolicus). The average identification accuracy of about $90 \%$ was found for $A$. maximowiczii. The similar result was shown for the samples of $A$. middendorffii, which showed a relatively low accuracy (about $71-77 \%$ ) only in comparison with $A$. gromovi.

We did not study qualitative characters in this paper, however we can compare consensus configurations (Fig. 6) as a kind of references for species identification. We did not find differences between $A$. maximowiczii-A. middendorffii (mdA), and A. mujanensis-A. evoronensis. All other species also have overlapping morphology (Figs 2 and 3) which complicates the species identification. We list some notes on qualitative features below.

A. the presence of "oeconomus-like" fusion of AC and fifth triangles. This character is ordinary in $A$. oeconomus (97\%), often in A. mongolicus $(53.8 \%)$ and in A. gromovi (58\%). Other teeth samples (A. fortis, $A$. maximowiczii, A. middendorffii, $A$. mujanensis and $A$. evoronensis) also contain some "oeconomus-like" morphotypes (2-3\%) (Fig. 7 a-f).

B. simplified buccal side of AC ("fortis-like"). This character is ordinary in A. fortis $(70.3 \%)$. But was found also in A. maximowiczii $(6.5 \%)$, A. oeconomus (7.6\%), A. sachalinensis (IBSS-7799, IBSS-10944) $(<$ 2\%) (Fig. $7 \mathrm{~g}-\mathrm{i})$. 

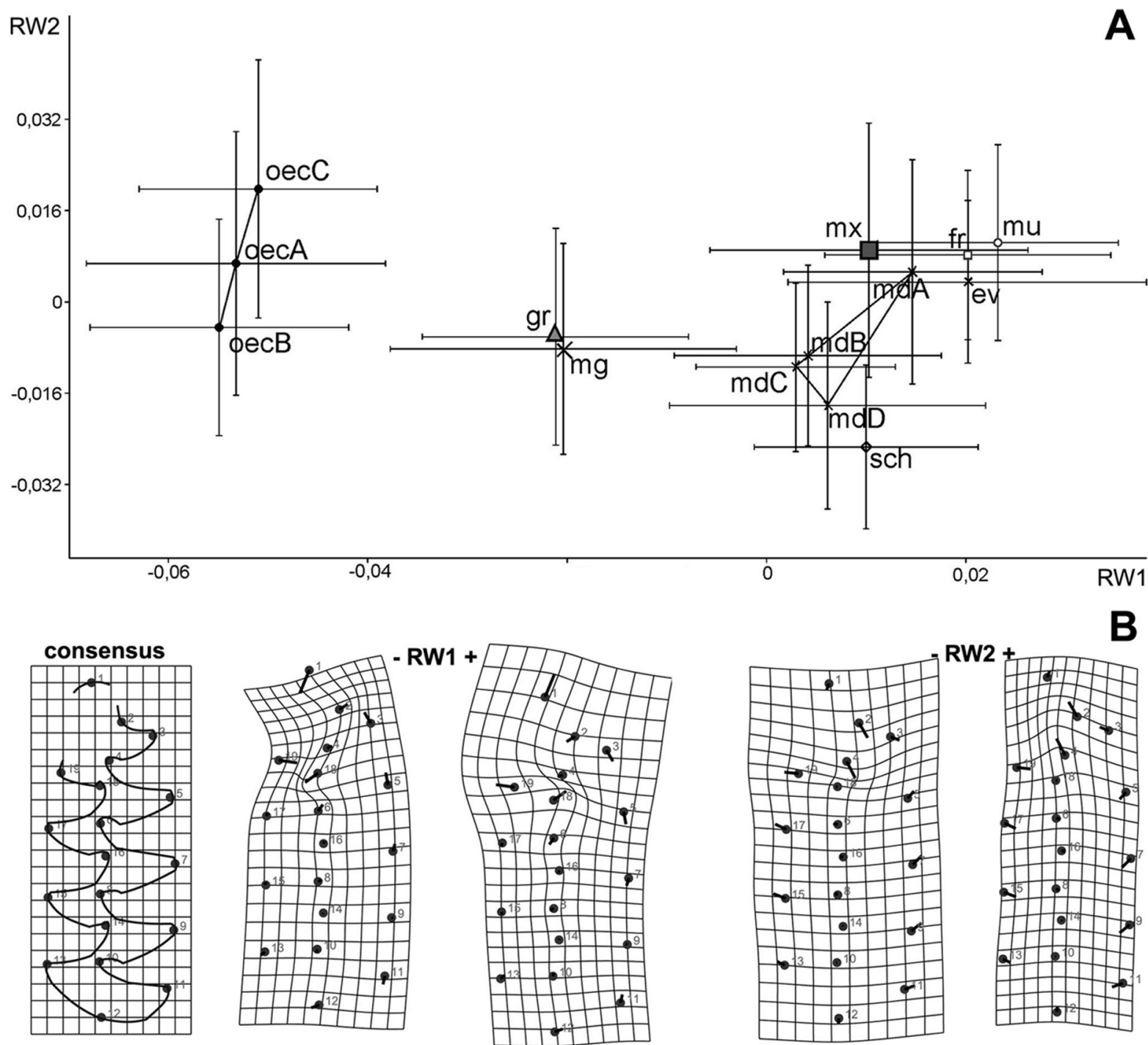

RW2

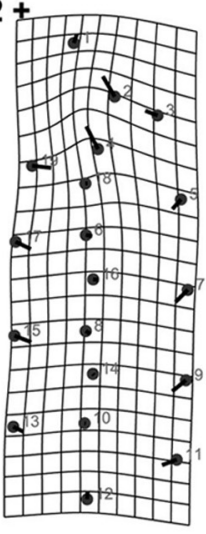

Figure 3. Variation of $\mathrm{m} 1$ in the plain of the first two relative warps. A - scatterplot of RW1 against RW2: means and standard deviation are shown. B - transformation grids of RW1 and RW2. For abbreviations see Fig. 2.

C. prominent fourth buccal salient angle (BSA 4). The character occurs in all studied species (Fig. 7 l-q).

D. buccal and/or lingual additional enamel fold on AC. This feature tends to characterize complication of the occlusal surface. It was found in A. maximowiczii (about 1\%), A. middendorffii (4.7\%); more often in $A$. mujanensis (23.6\%) and A. evoronensis (23.5\%) (Fig. $7 \mathrm{r}-\mathrm{w}$ ).

E. presence of isolated dentine islet inside the anterior part of AC. The feature occurs in A. maximowiczii $(<1 \%)$, A. mujanensis $(5.5 \%)$ and A. evoronensis $(<$ $1 \%)$ (Fig. $7 \mathrm{x}$ ).

\section{Discussion}

Species identification of Far-Eastern voles is usually based on the combination of quantitative and qualitative characters. Many papers studied variation of $\mathrm{ml}$ morphotypes (Rabeder, 1981; Agadzhanian \& Yatsenko, 1984; Pozdniakov, 1993; Kazantseva \& Tesakov, 1998; Martin, 1998; Courant et al., 1999; Tesakov, 2005).

As was aforementioned, it is impossible to identify species on the basis of qualitative features only. This is due to wide overlapping of morphology of enamel loops. Quantitative parameters can add useful informa- 


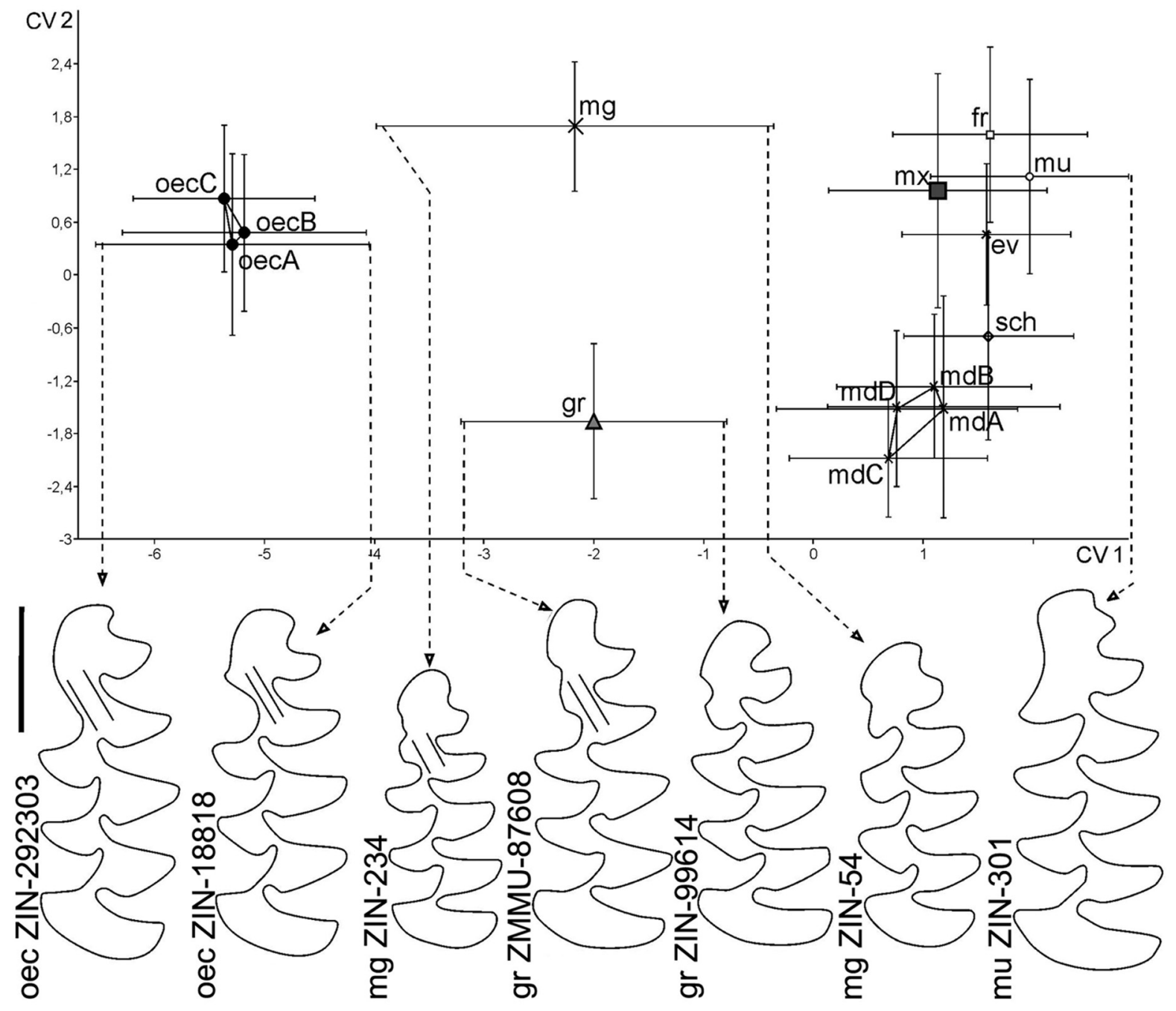

Figure 4. Scatterplot of the first two canonical variables: means and standard deviation as well as marginal morphotypes are shown. For abbreviations see Fig. 2. Scale bar $=1 \mathrm{~mm}$.

tion for species identification. Linear measurements can differentiate the smallest species, A. mongolicus, from large-sized species (A. fortis, A. mujanensis, A. evoronensis, $A$. sachalinensis). The main differences in shape are associated with "oeconomus-like" fusion, which clearly differentiates the root vole, Mongolian and Gromov's voles from other species. Differences between other species are associated with proportions of $\mathrm{AC}$ base and basal part of $\mathrm{m} 1$. Linear measurements together with shape features can be used for identification of the following pairs of species: A. oeconomus vs. A. mongolicus, A. sachalinensis vs. A. middendorffii (B-D). In other cases it should be noted that species clouds widely overlap and visual identification in the frame of current dataset seems less probable.

The features, which differentiate morphologically similar species, have quantitative character and can not be used for visual identification.
Consensus configurations of $A$. maximowiczii and A. middendorffii are very similar (Fig. 6). Only a half of the sample of these species was identified correctly following published identification keys (Orlov et al., 1974; Gromov \& Erbaeva, 1995; Meyer et al., 1996). Our study displays the percentage of correct classification for these species ranged between $87 \%$ and $96.5 \%$ (Tab. 3). Thus, geometric morphometrics techniques allow successful species identification in some cases. It is important to note here that our landmarks wireframe did not describe the anterior cap folding variation, which is usually used for the species identification.

The result of cluster analysis (Fig. 5) generally does not agree with results of molecular studies (Bannikova et al., 2010; Lissovsky et al., 2010; Haring et al., 2011). Only three species: A. maximowiczii, A. mujanensis, $A$. evoronensis, group together according to their 


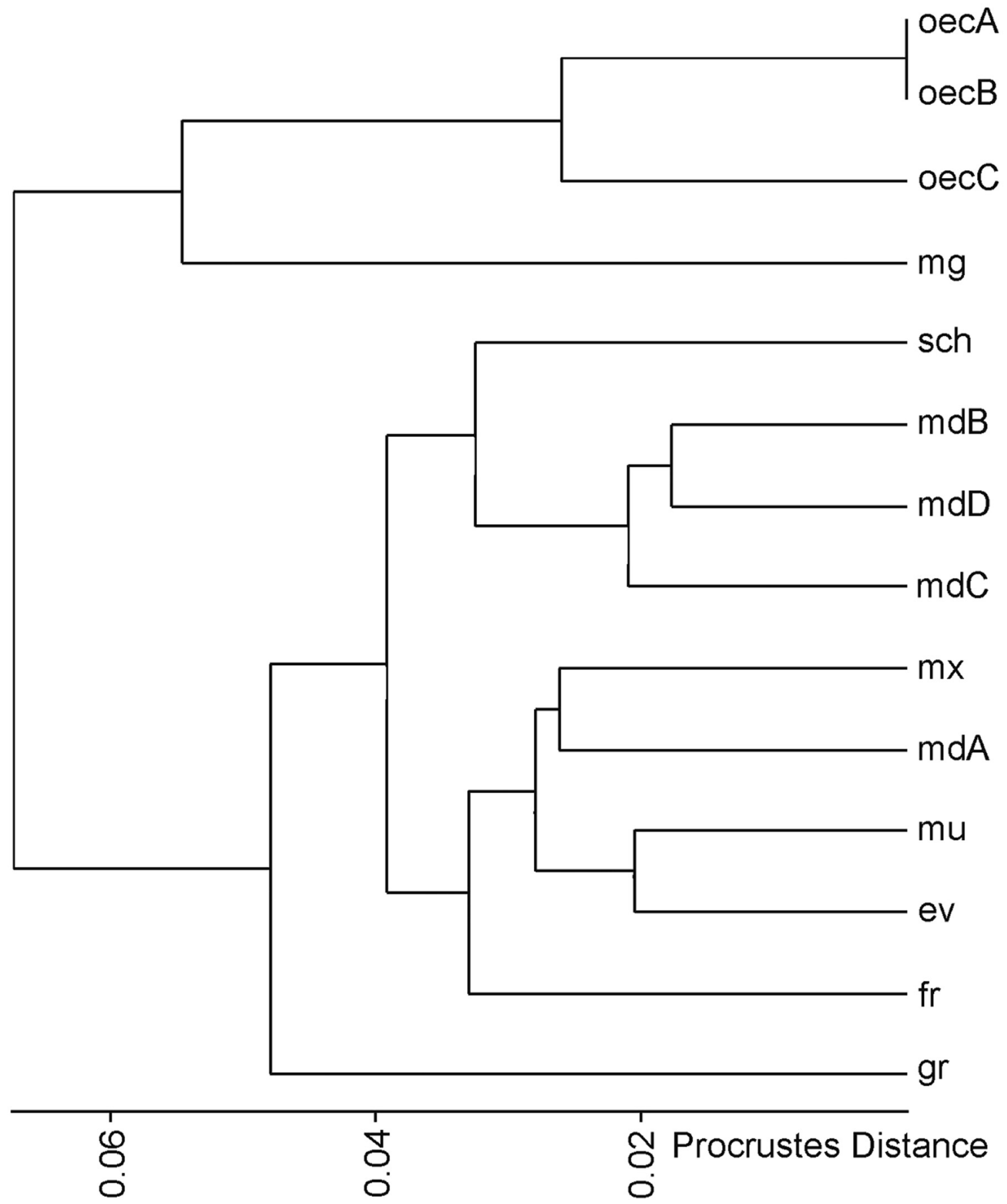

Figure 5. Dendrogram of morphometric similarity of $\mathrm{m} 1$ shape. For abbreviations see Fig. 2.

phylogenetic position based on mitochondrial sequences. However these three species are very close to each other phylogenetically, so several authors discussed their aggregation in one species $A$. maximowiczii (Frisman et al., 2009; Lissovsky \& Obolenskaya, 2011; Haring et al., 2011; Abramson \& Lissovsky, 2012).

Cluster analysis unites together $A$. oeconomus and A. mongolicus with rather big distance between them.
Phylogenetically sister species $A$. mongolicus, $A$. middendorffii and $A$. gromovi are separated in different branches of the dendrogram. Position of A. fortis, $A$. sachalinensis, $A$. maximowiczii branches also disagrees with the results of molecular studies. Thus, the shape of the first lower molar of Far-Eastern grey voles can be used for species identification, but not for phylogenetic analysis. 


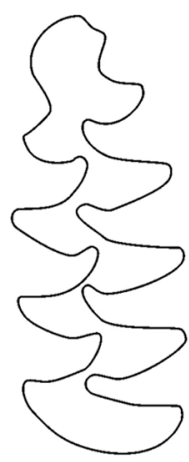

ev

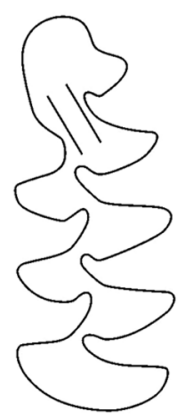

oecA
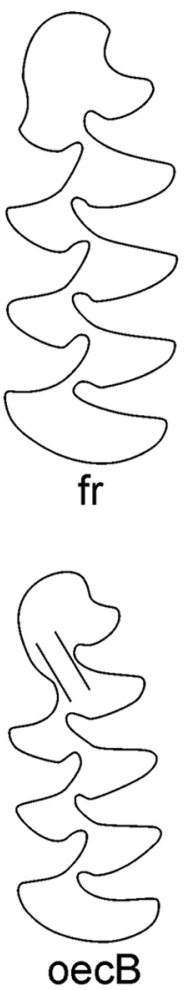

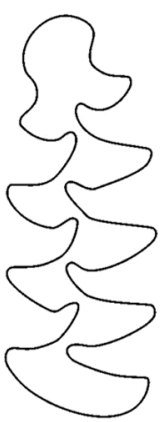

$\mathrm{mx}$

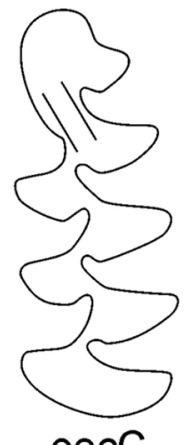

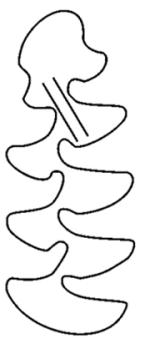

$\mathrm{mg}$

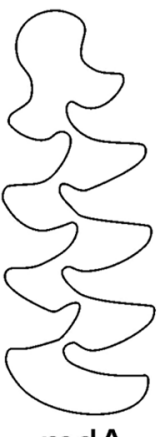

mdA
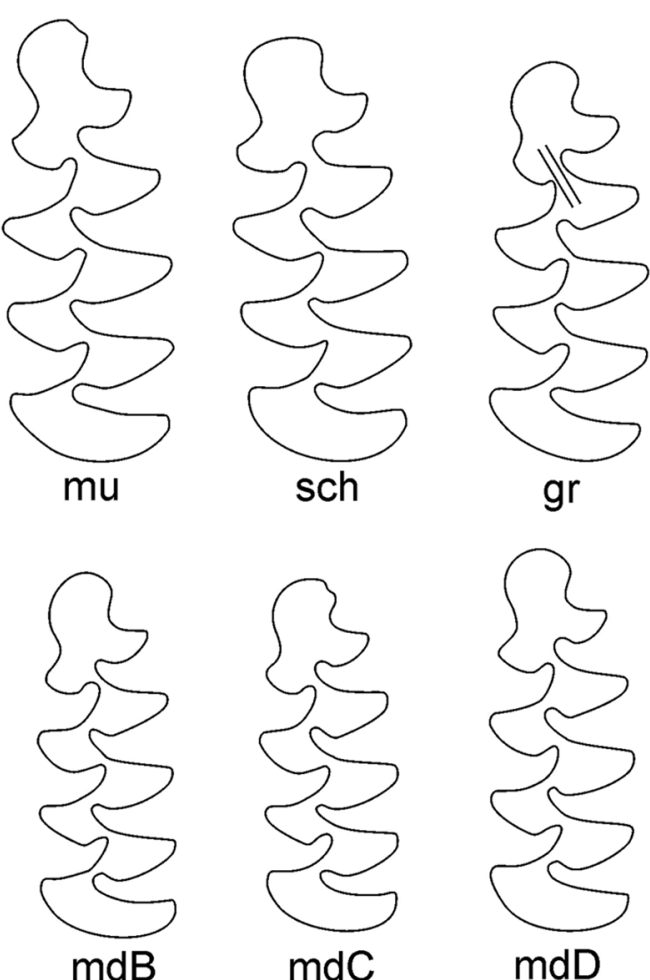

Figure 6. Consensus configurations of samples. For abbreviations see Fig. 2. Scale bar $=1 \mathrm{~mm}$.
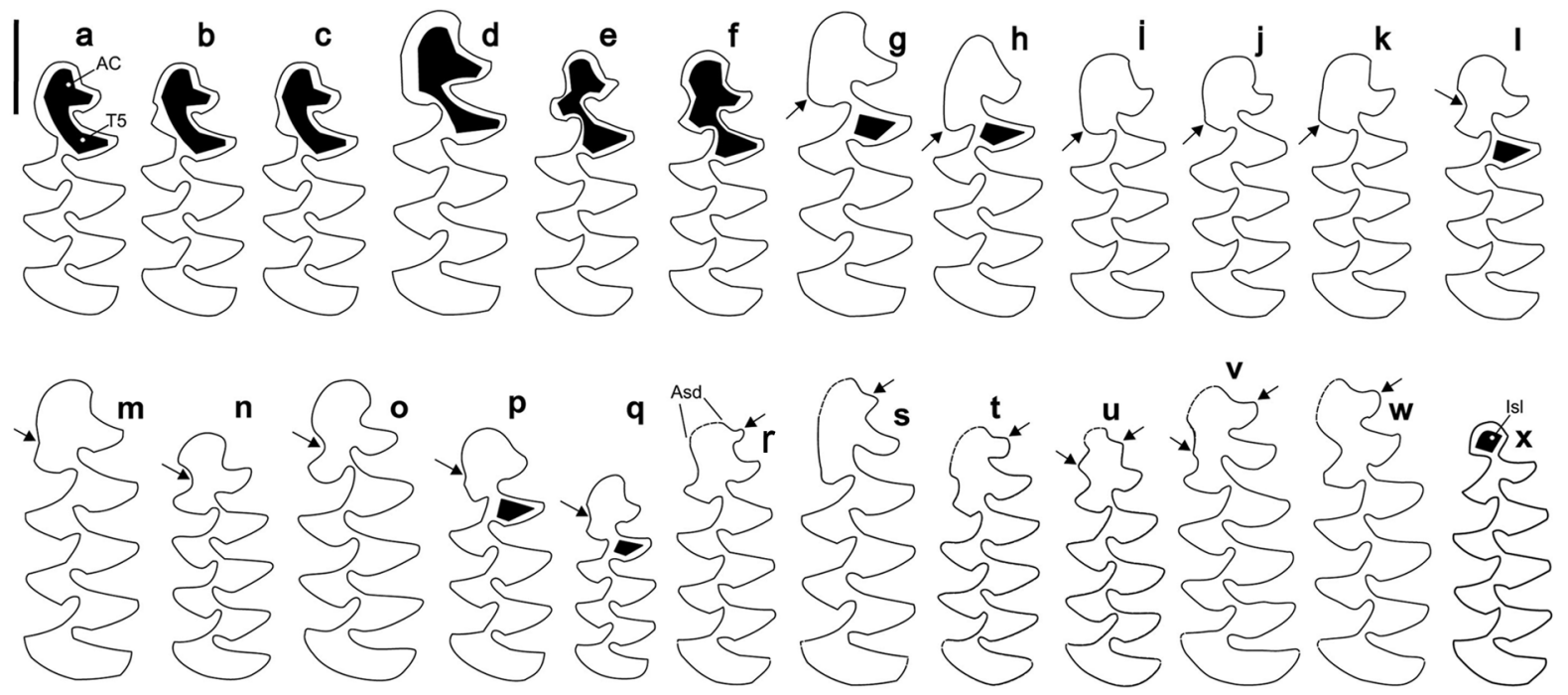

Figure 7. Examples of $\mathrm{m} 1$ occlusal surface of Alexandromys. a-f — "oeconomus-like" fusion of anterior cap (AC) and fifth lingual triangle (T5) ( $\mathrm{a}$ - consensus configuration of A. oeconomus; $\mathrm{b}-$ A. oeconomus ZIN-64347; c - A. oeconomus ZIN18821; d - A. fortis from Far-Eastern sample (IBSS collection); e, f $-A$. maximowiczii from Amalat River, Buryatia Republic). g-k — "fortis-like" simplified buccal side of AC (g - consensus configuration of A. fortis; $\mathrm{h}$ - A. oeconomus ZIN-5423; i - A. maximowiczii IBSS-253/8133; j - A. maximowiczii from Podoinitsino Village, Zabaikalskiy Territory; $\mathrm{k}-$ A. maximowiczii from Romanovka Village, Buryatia Republic). $\mathbf{l}-\mathbf{q}$ - the fourth buccal salient angle presents ( 1 - consensus configuration of $A$. maximowiczii; $\mathrm{m}-$ A. fortis ZIN-18832; $\mathrm{n}-A$. middendorffii IPAE-401; o - A. middendorffii IPAE421; $\mathrm{p}-$ A. oeconomus from Amalat River, Buryatia Republic; $\mathrm{q}-$ A. mongolicus ZIN-54). $\mathbf{r}-\mathbf{w}$ - supplementary cusps on buccal or lingual sides of anteroconid cap relative to anterior dentine tract (Asd) ( $\mathrm{r}$ - A. maximowiczii ZIN-18802; $\mathrm{s}$ A. fortis ZIN-11; t - A. middendorffii IPAE-460; u - A. middendorffii ZIN-67; v - M. evoronensis ZIN-78989; w A. mujanensis ZIN-64909). $\mathbf{x}$ - anteroconid anterior dentine islet (Isl) (A. mujanensis ZIN-276). Scale bar $=1 \mathrm{~mm}$. 


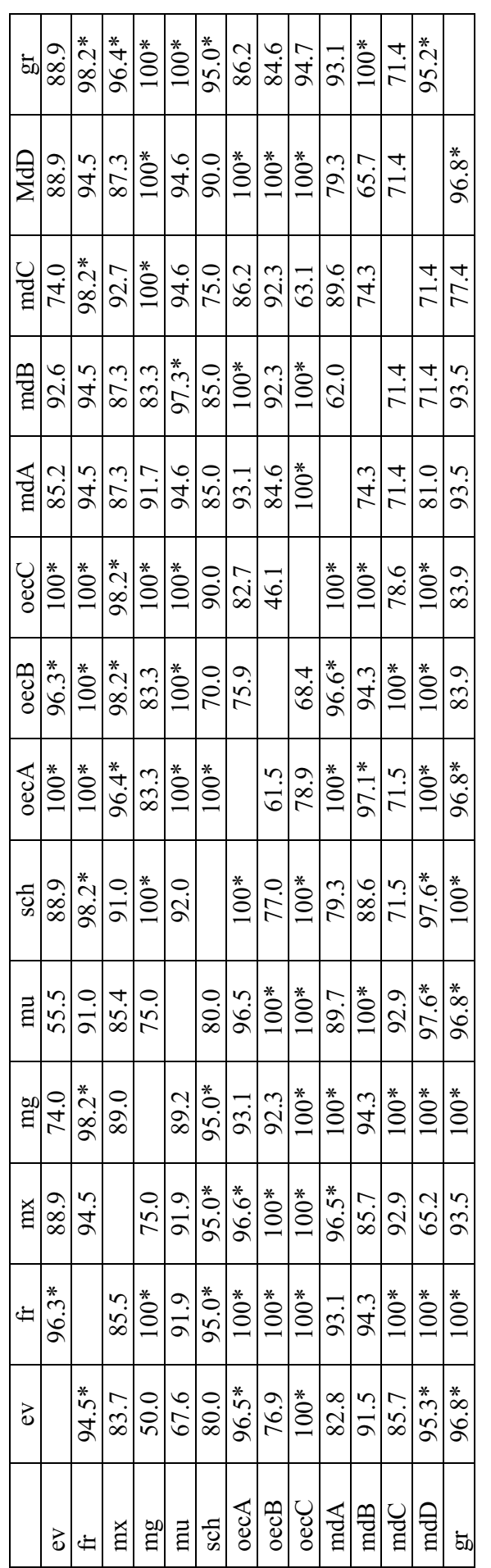

ACKNOWLEDGMENTS. We are grateful to our colleagues: A.O. Averianov, A.A. Lissovsky, A.S. Tesakov, G.I. Baranova, E.A. Pertova, A.Yu. Puzachenko, I.V. Kartavtseva, I.N. Sheremetyeva, E.V. Obolenskaya, V.S. Lebedev, N.I. Abramson, V.G. Malikov, L.I. Ivanov, N. Riabkova, A.G. Vasil'ev, T.P. Kaurova, O.A. Burkovskiy, V.A. Kostenko, V.E. Panasenko, E.I. Zholnerovskaja, Z.P. Vachrusheva, I.Ya. Pavlinov, A. Cardini, P. O'Higgins and P.D. Polly. This work was supported in part by the Ministry of Education and Science of Russian Federation, RFFI 10-0600060-a, RFFI 11-04-90722-mob st, RFFI 12-04-00937-a, RFFI 12-04-00662-a, RFFI 13-04-00930-a, RFFI 13-0400525-a, Program "Biodiversity" of Presidium of the Russian Academy of Sciences, Project no. VIII.76.3.5 of Fundamental Researches of the Siberian Division of the Russian Academy of Sciences.

\section{References}

Abramson N.I. \& Lissovsky A.A. 2012. Subfamily Arvicolinae Gray 1821 // Pavlinov I.Ya. \& Lissovsky A.A. (eds.). The Mammals of Russia: A Taxonomic and Geographic Reference. (Archives of Zoological Museum of MSU. Vol.52). Moscow: KMK Sci Press. P.220-276.

Agadzhanian A.K. \& Yatsenko V.N. 1984. [Phylogenetic relationships of North Eurasian voles] // Rossolimo O.L. (ed.). [Problems of variation and phylogeny of mammals]. Moskva: Izdatel'stvo Moskovskogo Gosudarstvennogo Universiteta. P.135-190 [in Russian].

Angermann R. 1973. [Homologous variation of molars in voles (Microtinae)] // Vorontsov N.N. (ed.). [Problems of Evolution]. Vol.3. Novosibirsk: Izdatel'stvo Nauka. P.104-118 [in Russian, with English summary].

Bannikova A.A., Lebedev V.S., Lissovsky A.A., Matrosova V., Abramson N.I., Obolenskaya E.V. \& Tesakov A.S. 2010. Molecular phylogeny and evolution of the Asian lineage of vole genus Microtus (Rodentia: Arvicolinae) inferred from mitochondrial cytochrome $b$ sequence // Biological Journal of the Linnean Society. Vol.99. P.595613.

Baryshnikov G.F. \& Puzachenko A.Yu. 2009. Craniometrical variability in insular populations of brown bear ( $U r$ sus arctos, Carnivora) from Hokkaido, Sakhalin and South Kurils // Proceedings of the Zoological Institute RAS. Vol.313. No.2. P.119-142.

Bookstein F.L. 1991. Morphometric Tools for Landmark Data: Geometry and Biology. Cambridge: Cambridge University Press. 435 p.

Butler P.M. 1985. Homologies of molar cusps and crests, and their bearing on assessment of rodent phylogeny // Luckett W.P. \& Hartenberger J.-L. (eds.). Evolutionary Relationships among Rodents: A Multidisciplinary Analysis. New York: Plenum Press. P.381-401.

Caumul R. \& Polly P.D. 2005. Phylogenetic and environmental components of morphological variation: skull, mandible, and molar shape in marmots (Marmota, Rodentia) // Evolution. Vol.59. P.2460-2472.

Courant F., Brunet-Lecomte P., Volobuev V., Chaline J., Quéré J.P., Nadachowski A., Mountire S., Bao G., Viriot L., Rausch R., Erbajeva M., Shi D. \& Girauduox P. 1999. Karyological and dental identification of Microtus limnophilus in a large focus of alveolar echinococcosis 
(Gansu, China) // Comptes Rendus de L'Académie des Sciences. Série 3. Sciences de la Vie. Vol.322. P.473480.

Frisman L.V., Korobitsyna K.V., Kartavtseva I.V., Sheremetyeva I.N. \& Voyta L.L. 2009. Voles (Microtus Schrank, 1798) of the Russian Far East: allozymic and karyological divergence // Russian Journal of Genetics. Vol.45. No.6. P.707-714.

Gileva E.A. 1972. [Chromosomal polymorphism in two related taxa of subarctic voles (North Siberian vole and Middendorff's vole)] // Doklady Akademii Nauk SSSR. Vol.203. No.3. P.689-692 [in Russian].

Golenishchev F.N. 1982. [Grey voles (subgenus Microtus, species-group "maximowiczii") of East Siberia and Far East]. PhD Thesis. Leningrad: Zoologicheskii Institut AN SSSR. 23 p. [in Russian].

Gromov I.M. \& Erbajeva M.A. 1995. [The Mammals of Russia and Adjacent Territories. Lagomorphs and Rodents]. Sankt-Peterburg: Izdatel'stvo Zoologicheskogo Instituta. 520 p. [in Russian].

Gromov I.M., Gureev A.A., Novikov G.A., Sokolov I.I., Strelkov P.P. \& Chaptsky K.K. 1963. [Mammals of Fauna of USSR. Part1.]. Moskva-Leningrad: Izdatelstvo Akademii Nauk SSSR. 638 p. [in Russian].

Gromov I.M. \& Polyakov I.Ya. 1977. [Fauna of the USSR, Voles (Microtinae): Mammals]. Leningrad: Izdatel'stvo Nauka. Vol.3. No.8. 504 p. [in Russian].

Hammer Ø, Harper D.A.T. \& Ryan P.D. 2001. Paleontological Statistics Software Package for Education and Data Analysis // Palaeontologia Electronica. Vol.4. P.1-9.

Haring E., Sheremetyeva I.N. \& Kryukov A.P. 2011. Phylogeny of Palearctic vole species (genus Microtus, Rodentia) based on mitochondrial sequences // Mammalian Biology. Vol.76. P. 258-267.

Hinton M.A.C. 1929. Monograph of the Voles and Lemmings (Microtinae) Living and Extinct. London: British Museum (Natural History). Vol.1. 488 p.

Kartavtseva I.V., Sheremetyeva I.N., Korobitsina K.V., Nemkova G.A., Konovalova E.V., Korablev V.V. \& Voyta L.L. 2008. Chromosomal forms of Microtus maximowiczii (Schrenck, 1859) (Rodentia, Cricetidae): variation in $2 \mathrm{n}$ and NF in different geographic regions // Russian Journal of Theriology. Vol.7. No.2. P.89-97.

Kazantseva N.E. \& Tesakov A.S. 1998. Evolution of PlioPleistocene voles with the special reference to demographic features of fossil assemblages // Mededelingen Nederlands Instituut voor Toegepaste Geowetenschappen TNO. Vol.60. P.555-564.

Klingenberg C.P. 2011. MorphoJ: an integrated software package for geometric morphometrics // Molecular Ecology Resources. Vol.11. P.353-357.

Koenigswald W. 1980. Schmelzstruktur und Morphologie in den Molaren der Arvicolidae (Rodentia) // Abhandlungen der Senckenbergischen Naturforschenden Gesellschaft. Bd.539. 129 p.

Kotlia B.S. \& Mathur D.P. 1992. Morphologic, sinumetric and enamel investigation of the Pliocene arvicolids (Rodentia) from the Karewas of the Kashmir, India // Geobios. Vol.25. No.6. P.781-796.

Kovalskaja Yu.M., Khotolhu N. \& Orlov V.N. 1980. [Geographical distribution of chromosomal mutations and intraspecific structure of Microtus maximowiczii (Rodentia, Cricetidae)] // Zoologicheskii Zhurnal. Vol.59. No.12. P.1862-1869 [in Russian].

Kuziakin A.P. 1963. [To the systematics of Rodents of fauna of USSR] // Trudy Moskovskogo Obshestva Ispytatelei Prirody. Vol.10. P.105-115 [in Russian].

Larina N.I. 1974. [To the method of age determination in rootless voles group] // Shlyakhtin G.V. (ed.). [Physiological and Population Ecology of Animals]. Vol.2. No.4. Saratov: Izdatel'stvo Saratovskogo Universiteta. P.9297 [in Russian].

Lissovsky A.A., Obolenskaya E.V., Abramson N.I., Dokuchaev N.E., Yakimenko V.V., Mal'kova M.G., Bogdanov A.S. \& Ivanova N.V. 2010. Geographic variation of Microtus middendorffii (Cricetidae, Arvicolinae, Rodentia) sensu lato studied by craniometrical and mitochondrial features // Russian Journal of Theriology. Vol.9. No.2. P.71-81.

Lissovsky A.A. \& Obolenskaya E.V. 2010. [Structure of craniometric variation of root vole (Microtus oeconomus, Rodentia)] // Zoologicheskii Zhurnal. Vol.89. No.6. P.1-5 [in Russian, with English summary].

Lissovsky A.A. \& Obolenskaya E.V. 2011. [The structure of craniometrical diversity of grey voles Microtus subgenus Alexandromys] // Proceedings of Zoological Institute RAS. Vol.315. No.4. P.461-477 [in Russian, with English summary].

Litvinov Yu.N. 2001. [Communities and Populations of Small Mammals in Siberian Ecosystems]. Novosibirsk: Izdatel'stvo TSERIS. 128 p. [in Russian].

Martin R.A. 1998. Time's arrow and the evolutionary position of Orthriomys and Herpethomys // Paludicola. Vol.2. No.1. P.70-73.

McGuire J.L. 2010. Geometric morphometrics of vole (Microtus californicus) dentition as a new paleoclimate proxy: shape change along geographic and climatic clines // Quaternary International. Vol.212. P.198-205.

McGuire J.L. 2011. Identifying California Microtus species using geometric morphometrics documents Quarternary geographic range contractions // Journal of Mammalogy. Vol.92. No.6. P.1383-1394

Meyer M.N., Golenishchev F.N., Radjably S.I. \& Sablina O.V. 1996. [Voles (Subgenus Microtus Schrank) of Russia and Adjacent Territories]. (Proceedings of the Zoological Institute. Vol.232.). Sankt-Peterburg: Izdatel'stvo Rossiiskoi Akademii Nauk. 320 p. [in Russian].

Ognev S.I. 1950. [The Mammals of the USSR and Adjacent Territories. Rodents]. Vol.7. Moskva-Leningrad: Izdatel'stvo AN SSSR. 706 p. [in Russian].

Orlov V.N., Shvetsov Yu.G., Kovalskaya Yu.M., Kutashova T.S. \& Stupina A.G. 1974. [Diagnosis and distribution of voles Microtus maximowiczii and M. fortis (Rodentia, Cricetidae) within Transbaikalia]// Zoologicheskii Zhurnal. Vol.53. No.9. P.1391-1396 [in Russian].

Polly P.D. 2007. Phylogeographic differentiation in Sorex araneus: morphology in relation to geography and karyotype // Russian Journal of Theriology. Vol.6. P.73-84.

Poljakov I.S. 1881. [Taxonomical review of Siberian voles] // Zapiski Imperatorskoy Akademii Nauk. Vol.39. Suppl.2. P.1-91 [in Russian]. 
Pozdniakov A.A. 1993. [Morphotypical variation of molar teeth occlusal surface of the grey voles of species-group "maximowiczii" (Rodentia, Cricetidae): an experience of quantitative statistic analysis] // Zoologicheskii Zhurnal. Vol.72. No.11. P.114-125 [in Russian].

Rabeder G. 1981. Die Arvicoliden (Rodentia, Mammalia) aus dem Pliozän und dem älteren Pleistozän von Niederösterreich // Beiträge der Paläontologisch Österreich. Bd.8. S.1-373.

Rohlf F.G. \& Slice D.E. 1990. Extension of the Procrustes method for the optimal superimposition of landmarks // Systematic Zoology. Vol.39. P.40-59.

Rörig G. \& Börner C. 1905. Studien über das Gebiss mitteleuropäischer rezenter Mäuse // Arbeiten aus der Kaiserlichen Biologischen Anstalt für Land- und Forstwirtschaft. Bd.5. No.2. P.37-89.

Sheets H.D. 2001. IMP Software Series. Buffalo, New York, Canisius College.

Sheremetyeva I.N., Kartavtseva I.V., Voyta L.L., Kryukov A.P. \& Haring E. 2009. Morphometric analysis of intraspecific variation in Microtus maximowiczii (Rodentia, Cricetidae) in relation to chromosomal differentiation with reinstatement of Microtus gromovi Vorontsov et al., 1988, stat. nov. // Journal of Zoological Systematics and Evolutionary Research. Vol.47. P.42-48.

Sheremetyeva I.N., Kartavtseva I.V., Voyta L.L. \& Tiunov M.P. 2010. [New data on distribution of voles of the genus Microtus (Rodentia, Cricetidae) from the Russian Far East] // Zoologicheskii Zhurnal. Vol.89. No.10. P.1273-1276 [in Russian, with English summary].

Shenbrot G.I. \& Krasnov B.R. 2005. An Atlas of the Geographic Distribution of the Arvicoline Rodents of the World (Rodentia, Muridae: Arvicolinae). Sofia: Pensoft Publ. 336 p.

Tesakov A.S. 2005. Pliocene voles (Pliomys, Arvicolinae, Radentia) from Odessa Catacombs // Russian Journal of Theriology. Vol.4. No.2. P.123-135.

Tiunov I.M., Tiunov M.P. \& Sheremetyeva I.N. 2009. [Findings of Mongolian toad (Bufo raddei) and reed vole (Microtus fortis) on Sakhalin Island] // Zoologicheskii Zhurnal. Vol.88. No.11. P.1406-1408 [in Russian, with English summary].

Van der Meulen A.J. 1973. Middle Pleistocene smaller mammals from the Monte Peglia (Orivieto, Italy) with special reference to the phylogeny of Microtus (Arvicolidae, Rodentia)// Quaternaria. Vol.17. P.1-144.

Vinogradov B.S. 1933. [Mammals of USSR. Rodents]. Leningrad: Izdatel'stvo AN SSSR. 87 p. [in Russian].

Vinogradov B.S. \& Gromov I.M. 1952. [The Rodents of Fauna of USSR]. Leningrad: Izdatel'stvo AN SSSR. 298 p. [in Russian].

Vorontsov N.N., Boeskorov G.G., Lyapunova E.A. \& Revin Yu.V. 1988. [A new chromosome form and variation in Microtus maximowiczii (Rodentia, Cricetidae)] // Zoologicheskii Zhurnal. Vol.67. No.2. P.205-213 [in Russian, with English summary].

Voyta L.L. \& Golenishchev F.N. 2007. [Geometric morphometrics of molars in three species of the common field voles, the subgenus Alexandromys (Rodentia: Cricetidae: Microtus)] // Rozhnov V.V. \& Tembotova F.A. (eds.). [Mammals of Mountain Territories]. Moskva: KMK Scientific Press. P.79-84 [in Russian].

Voyta L.L. \& Golenishchev F.N. 2008. Analysis of variation of the molars in grey voles Microtus Schrank, 1798 (Rodentia: Cricetidae: Arvicolinae) using methods of geometric morphometrics // Abstracts of the 11-th International Conference on Rodent Biology. Rodents et Spatium. Myshkin, Russia, 24-28 July 2008. Moscow: KMK Sci Press. P.149-150.

Voyta L.L., Golenishchev F.N., Tiunov M.P. \& Panasenko V.E. 2011. Some restrictions of the morphometric methods as applied to classification of fossil remains of Sorex (Eulipotyphla: Soricidae) and Microtus (Rodentia: Cricetidae) // Abstracts of the 6-th European Congress of Mammalogy. Paris, France, 19-23 July 2011. Paris: Université Pierre et Marie Curie. P.39.

Zagorodnyuk I.V. 1990. [Karyotypic variation and systematics of the grey voles (Rodentia, Arvicolini). Communication 1. Species composition and chromosomal numbers] // Vestnik Zoologii. Vol.2. P.26-37 [in Russian].

Zelditch M.L., Swiderski D.L., Sheets H.D. \& Fink W.L. 2004. Geometric Morphometrics for Biologists: A Primer. San Diego: Elsevier Academic Press. 437 p.

Zimmermann K. 1952. Die Simplex-Zahnform der Feldmaus Microtus arvalis Pallas // Verhandlung der Deutschen Zoologischen Gesellschaft. Bd.46. P.492-498.

Zimmermann K. 1959. Über eine Kreuzung von Unterarten der Feldmaus // Zoologische Jahrbucher. Bd.87. No.1-2. P.1-12.

\section{Appendix 1}

The list of specimens used in morphometrical analysis. Information is in the following order: scientific name, sample number in parenthesis, geographical locality, geographical coordinates in parenthesis, specimen ID (followed by field ID in parenthesis if needed), sample size in parenthesis.

A. evoronensis: (1) Evoron Lake, Khabarovsky Territory, Russia (5137’N, 136 52 ”'E) - 78986-78989, 78991, 78993, 79012, 79013 ZIN ( $=8$ ); (2) sample from captivity, originated from Evoron Lake - 100982 (3, 4, 5, 5a, 6, 6a, 7, 7a, 8, 9, 13, 16a, 19b, 41, 42, 47, 50, 1060, 1069) ZIN (n = 19).

A. fortis: (3) Klykov Island, Peter the Great Bay, the Sea of Japan, Primorskiy Territory, Russia $\left(42^{\circ} 58^{\prime} \mathrm{N}, 131^{\circ} 43^{\prime} \mathrm{E}\right)-$ 74908-74919, 74989 ZIN ( $=12$ ); (4) Sample from captivity, originated from Putiatin Island, Peter the Great Bay, the Sea of Japan, Primorskiy Territory, Russia $\left(42^{\circ} 52^{\prime} \mathrm{N}, 132^{\circ} 25^{\prime} \mathrm{E}\right)-100983(3,7,11,32,33,112,143,144,254,261,266,276)$ ZIN ( $=12)$; (5) Sergeevka Village, Primorskiy Territory, Russia $\left(43^{\circ} 21^{\prime} \mathrm{N}, 133^{\circ} 22^{\prime} \mathrm{E}\right)-18831,18832,18835,18838$, 18843, 18834 ZIN $(\mathrm{n}=6)$; (6) Sample from captivity, originated from Soktuy-Milozan Village, Zabaikalskiy Territory, Russia $\left(50^{\circ} 04^{\prime} \mathrm{N}, 117^{\circ} 47^{\prime} \mathrm{E}\right)-100984(35,41,119,131,138,156,164,207,243,277,306,311,316-318,510,521,666$, $707,708,724,738,746,750,766)$ ZIN $(\mathrm{n}=25)$. 
A. maximowiczii: (7) Ivan Lake, Zabaikalskiy Territory, Russia $\left(52^{\circ} 16^{\prime} \mathrm{N}, 113^{\circ} 00^{\prime} \mathrm{E}\right)-50190,50191,50193-50197$, 50202 ZIN ( $\mathrm{n}=8)$; (8) Bolshoi Never Railway Station, Amur Region, Russia $\left(53^{\circ} 59^{\prime} \mathrm{N}, 124^{\circ} 09^{\prime} \mathrm{E}\right)-18799,18800,18802-$ 18808 ZIN ( $=9$ ); (9) Sample from captivity, originated from Soktuy-Milozan Village, Zabaikalskiy Territory, Russia $\left(50^{\circ} 04^{\prime} \mathrm{N}, 117^{\circ} 47^{\prime} \mathrm{E}\right)-100985(33,35,94,221,222,240,290,514) \mathrm{ZIN}(\mathrm{n}=8)$; (10) Zeiskiy Nature Reserve, Amur Region, Russia $\left(53^{\circ} 45^{\prime} \mathrm{N}, 127^{\circ} 17^{\prime} \mathrm{E}\right)-70176(249,317,346,350,352,403,432,442,488,446,474,640,641,799,803), 70177$ $(128,251,309,316,341,342,354,430,437,456,457,472,499,788,804)$ ZIN (n = 30).

A. mongolicus: (11) Sample from captivity, originated from Soktuy-Milozan Village, Zabaikalskiy Territory, Russia $\left(50^{\circ} 04^{\prime} \mathrm{N}, 117^{\circ} 47^{\prime} \mathrm{E}\right)-100986(54,58,88,105,186,216,223,224,234,237,238,279)$ ZIN $(\mathrm{n}=12)$.

A. mujanensis: (12) Muja and Kuanda Rivers basin, Buryatia Republic and Zabaikalskiy Territory, Russia $\left(52^{\circ} 45^{\prime} \mathrm{N}\right.$, $\left.115^{\circ} 67^{\prime} \mathrm{E}\right)-64902,64905,64907,64909,64910,64912,64918,64923,64924 \mathrm{ZIN}(\mathrm{n}=9)$; (13) Sample from captivity, originated from Muja and Kuanda rivers basin, Buryatia Republic and Zabaikalskiy Territory, Russia $\left(52^{\circ} 45^{\prime} \mathrm{N}, 115^{\circ} 67^{\prime} \mathrm{E}\right)-$ $100987(17,37,48,55,94,109,117,120,137,139,161,162,168,169,186,190,207,226,229,238,239,242,276,279$, 281, 282, 299, 301) ZIN (n = 28).

A. sachalinensis: (14) Sample from captivity, originated from Nevskoe Lake, Sakhalin Island, Russia $\left(49^{\circ} 419^{\prime} \mathrm{N}\right.$, $\left.143^{\circ} 34^{\prime} \mathrm{E}\right)-100988(2,5,8,9,11,32,54,121,136,145,149,150,159,177,179,186,217,224,225,253)$ ZIN $(\mathrm{n}=20)$.

A. oeconomus: (15) Tukuringra Ridge, northward from Bolshoi Never railway station, Amur Region, Russia (about $54^{\circ} \mathrm{N}$, $\left.122^{\circ} \mathrm{E}\right)-18818-18822 \mathrm{ZIN}(\mathrm{n}=5)$; (16) Belbei Village, Tuva Republic, Russia $\left(51^{\circ} 17^{\prime} \mathrm{N}, 95^{\circ} 46^{\prime} \mathrm{E}\right)-64347-64350$, 64352, 64353, 64355 ZIN ( $=7$ ); (17) Matua Island, Kurile Chain, Sakhalinskaya Region, Russia $\left(48^{\circ} 04^{\prime} \mathrm{N}, 153^{\circ} 13^{\prime} \mathrm{E}\right)-$ 2845-2847, 2850, 2852, 2866, 2867, 2869, 2918, 2920-2924, 2927, 2939, 2941 IBSS ( $\mathrm{n}=17$ ); (18) The Ossora Village, Kamchatskiy Territory, Russia $\left(59^{\circ} 15^{\prime} \mathrm{N}, 163^{\circ} 03^{\prime} \mathrm{E}\right)-5360,5362,5363,5378,5384,5385,5427,5437,5444,5455,5456$, 5459, 5461 IBSS ( $=13)$; (19) The Shumshu Island, Kurile Chain, Sakhalinskaya Region, Russia $\left(50^{\circ} 52^{\prime} \mathrm{N}, 156^{\circ} 29^{\prime} \mathrm{E}\right)-2752$, 2760, 2763, 2766, 2767, 2770, 2778, 2784-2786, 2795, 2804, 2816, 2828, 2832, 3084, 3104, 3106, 3111 IBSS (n = 19).

A. middendorffii: (20) Omoloy River, Yakutia Republic, Russia $\left(70^{\circ} 70^{\prime} \mathrm{N}, 133^{\circ} 26^{\prime} \mathrm{E}\right)-52496,52498,52500,52502$, $52507,52507,52509,52513,52517$ ZIN (n = 8); (21) Keta Lake, Taimyr Peninsula, Krasnoyarskiy Territory, Russia $\left(62^{\circ} 42^{\prime} \mathrm{N}, 90^{\circ} 38^{\prime} \mathrm{E}\right)-51542,51546-51548,51550,51553,51562,51563$ ZIN (n = 8); (22) Sample from captivity, originated from Tiksi, Yakutia Republic, Russia $\left(71^{\circ} 41^{\prime} \mathrm{N}, 128^{\circ} 52^{\prime} \mathrm{E}\right)-100989(34,41,42,46,62,66,67,78,137,166) \mathrm{ZIN}$ $(\mathrm{n}=10)$; (23) Yaptiksale Village, Yamal Peninsula, Tyumenskaya Region, Russia $\left(69^{\circ} 22^{\prime} \mathrm{N}, 72^{\circ} 31^{\prime} \mathrm{E}\right)-401,421,424,432$, 434, 460, 486, 487, 492, 495, 498, 499 IPAE ( $\mathrm{n}=12)$; (24) Labytnangi, Tyumenskaya Region, Russia $\left(66^{\circ} 39^{\prime} \mathrm{N}, 66^{\circ} 25^{\prime} \mathrm{E}\right)-$ 219, 236, 291, 304, 319, 320, 348, 525, 526, 528, 531, 532, 585 IPAE (n = 13); (25) Tiksi, Yakutia Republic, Russia $\left(71^{\circ} 41^{\prime} \mathrm{N}, 128^{\circ} 52^{\prime} \mathrm{E}\right)-7,8,56-64,78,303,306,313,314,340-342,348$ IPAE $(\mathrm{n}=20)$; (26) Sample from captivity, originated from Yamal Peninsula, Tyumenskaya Oblast, Russia (uncertain locality) - 266, 407, 425, 431, 436, 439, 440, 448, 455, 457, 476, 514, 544, 577 IPAE ( $=14)$; (27) Nelkan Village, Khabarovskiy Territory, Russia $\left(57^{\circ} 39^{\prime} \mathrm{N}, 136^{\circ} 10^{\prime} \mathrm{E}\right)-1$, 2, 42 FN IBSS $(\mathrm{n}=3) ;(28)$ Betenkes Village, Yakutia Republic, Russia $\left(67^{\circ} 37^{\prime} \mathrm{N}, 135^{\circ} 33^{\prime} \mathrm{E}\right)-100999(5,9,11,48,55,92)$, 70223-70225, 70232, 70233, 70235, 70236, 70239, 70240, 70706 ZIN ( $=16)$; (29) Sample from captivity, originated from Betenkes Village, Yakutia Republic, Russia $\left(67^{\circ} 37^{\prime} \mathrm{N}, 135^{\circ} 33^{\prime} \mathrm{E}\right)-71848-71850 \mathrm{ZIN}(\mathrm{n}=3)$; (30) Sample from captivity, originated from Batagay Village, Yakutia Republic, Russia $\left(67^{\circ} 39^{\prime} \mathrm{N}, 134^{\circ} 37^{\prime} \mathrm{E}\right)-150,163,171,197,230,235,236,238$, 249, 261, 273, 274, $276 \operatorname{IPAE}(\mathrm{n}=13)$.

A. gromovi: (31) Ayan Village, Khabarovskiy Territory, Russia $\left(56^{\circ} 27^{\prime} \mathrm{N}, 138^{\circ} 96^{\prime} \mathrm{E}\right)-99611-99614,99616-99621$ ZIN ( $\mathrm{n}=10)$; (32) Ayan Village, Khabarovskiy Territory, Russia $\left(56^{\circ} 27^{\prime} \mathrm{N}, 138^{\circ} 96^{\prime} \mathrm{E}\right)-\mathrm{S}-87601, \mathrm{~S}-87603, \mathrm{~S}-87608, \mathrm{~S}-$ 87615, S-87618, S-87620, S-87624, S-87636, S-87642, S-87674 ZMMU (n = 10); (33) Eldomu-Makit River, Khabarovskiy Territory, Russia $\left(55^{\circ} 47^{\prime} \mathrm{N}, 134^{\circ} 12^{\prime} \mathrm{E}\right)-\mathrm{S}-187545$, S-187546, S-187551, S-187552, S-187568 ZMMU (n = 5); (34) Uda River, Khabarovskiy Territory, Russia $\left(54^{\circ} 36^{\prime} \mathrm{N}, 135^{\circ} 06^{\prime} \mathrm{E}\right)-\mathrm{S}-176537$, S-176540, S-176548, S-176551, S-176556 ZMMU (n = 5); (35) Bolshoe Toko Lake, Yakutia Republic, Russia $\left(56^{\circ} 03^{\prime} \mathrm{N}, 130^{\circ} 51^{\prime} \mathrm{E}\right)-\mathrm{S}-140238 \mathrm{ZMMU}(\mathrm{n}=1)$.

\section{Appendix 2}

The list of specimens used in analysis of age variation. Information is in the following order: scientific name, sample number in conformity with Appendix 1, age stage, specimen ID (followed by field ID in parenthesis if needed). For abbreviations of age stages see Materials and Methods.

A. evoronensis:

(1) AD1 - 78986, 78987, 78993, 79012, $79013(\mathrm{n}=5)$; AD2 - 78988, 78989, $78991(\mathrm{n}=3)$. $10)$.

(2) AD1 - $100982(5 \mathrm{a}, 6,6 \mathrm{a}, 7-9,13,49,50)(\mathrm{n}=9)$; AD2 - $100982(3,4,7 \mathrm{a}, 16 \mathrm{a}, 19 \mathrm{~b}, 41,42,47,1060,1069)(\mathrm{n}=$

A. maximowiczii:

(7) $\mathrm{SAD}-50196(\mathrm{n}=1)$; AD1 - 50190, 50191, 50193, 50195, 50197, $50202(\mathrm{n}=6)$.

(8) AD1 - 18800, 18802, 18804, 18805, 18806-18808 (n=7); AD2 - 18799, $18803(\mathrm{n}=2)$.

(9) $\operatorname{AD} 2-100985(33,35,94,221,222,240,290,514)(\mathrm{n}=8)$.

(10) SAD - $70176(317,350,352,403), 70177(316,341,342,354)(\mathrm{n}=8)$; AD1 - $70176(442,446,474,640,799)$, $70177(128,430,456,457,788)(\mathrm{n}=10) ; \mathrm{AD} 2-70176(249,346,432,488,641,803), 70177(251,309,437,472,499,804)$ $(\mathrm{n}=12)$. 